\title{
New Records of Hermit Crab (Crustacea: Decapoda: Anomura) From Maharashtra Coast of India
}

\author{
T. Nirmal", A.K. Jaiswar, S.K. Chakraborty, A. Pavan Kumar, \\ G. Kantharajan and P.M. Nuzaiba
}

\begin{abstract}
ICAR-Central Institute of Fisheries Education, Panch Marg, Off Yari road Andheri (W), Mumbai- 400 061, India

*Corresponding author
\end{abstract}

A B S T R A C T

\begin{tabular}{|l}
\hline K e y w o r d s \\
Hermit crab, \\
Decapoda, \\
Paguroidea, \\
Anomura, \\
Maharashtra. \\
\hline Article Info \\
\hline $\begin{array}{l}\text { Accepted: } \\
\text { 23 June } 2017 \\
\text { Available Online: } \\
\text { 10 August } 2017\end{array}$ \\
\hline
\end{tabular}

\section{Introduction}

Hermit crabs placed under Decapoda (infraorder - Anomura) are the most attractive, distinctive and ecologically important group of animals extensively spread across the intertidal, subtidal, estuarine, mangrove and coral reef areas of tropical countries (Reese, 1969). This high variation in habitat where they resides makes them to evolve with various behavioral and physiological adaptations which possibly affect their diversity, distribution and their resource choice. These animals are known for their fragile and uncalcified abdomen for the reason they are highly reliance on gastropod shells which provide various services such as protection against predators and desiccation
(Reese, 1969; Hazlett, 1983). Anomurans form very important link in the food web of the oceans as the major food of economically valuable species of fishes. Anomura comprises of 7 super-families, 17 families, 200 genera, and about 1500 species worldwide (Martin and Davis, 2001). Under superfamily Paguroidea, hermit crabs comes which is further divided into 5 families with 1100 species worldwide. In Indian context, the hermit crabs were represented by 112 species (Trivedi and Vachhrajani, 2017) and this number is increasing day by day.

Majority of studies have been concentrated upon the organisms having high market value 
and the attention towards animal (hermit crabs) lacks this importance were less. Even though, there has been a series of regional faunal surveys took place along India viz. Henderson (1893, 1915), Alcock (1905), Southwell (1906), Sundara Raj (1927), Reddi (1935), Kamalaveni (1950), Khan, S.A. and R. Natarajan (1984) and Thomas (1989). In the interim, there have been a number of changes occurred in the nomenclature and systematics and new addition to the faunal list (Komai et al., 2012; 2013; 2015 and Reshmi and Bijukumar, 2010 and 2011). Even though, there are few works has been done, there exists uncertainty in both genus and species level which needs further more attention. Despite their ecological value, little is known about their systematics and ecology in India especially from Maharashtra region. Hence, there is a need for generating the information about the present status of hermit crabs which would form the baseline for further studies. The present investigation would facilitate subsequent recognition and identification of the involved taxon by the future reseachers for various diversity and ecological studies.

\section{Materials and Methods}

The samples of hermit crabs were collected by hand picking from intertidal areas during low tide, viz. Aksha beach, Bandstand of Mumbai and Alibaug, Srivardhan of Raigad and from trawlers operating in sub tidal areas of Versova of Mumbai, Maharashtra (Fig. 1) during August 2014 to April 2015. Collected animals, along with the shells were preserved in $70 \%$ alcohol and brought to lab for further studies. Later, the abdomen of the crabs was pulled out of the shells by twisting the animal slowly against the direction of shell spiral. A light hammer (Teoh et al., 2014) was used to crack the shell in difficult cases. The specimens were identified using the key (Alcock 1905; McLaughlin. 2003). Shield length (SL) measurements were taken from rostrum tip to the posterior edge of the shield to denote size. The reference materials were deposited in museum collections of Fisheries Resource Management Department, Central Institute of Fisheries Education, Mumbai (CIFE/FRM/HC1, 2, 5 and 8).

\section{Systematic accounts}

Family Diogenidae

Genus Clibanarius Dana, 1852

Clibanarius arethusa De Mann, 1888

Clibanarius arethusa De Man, 1888a: 252

\section{Materials examined}

Collected from rocky intertidal areas of Danapani, Bandstand and Srivardhan; Number of specimens examined: 3, 2 male (SL: 7.8, 9.2mm) and 1 female (SL: $5.8 \mathrm{~mm}$ ).

\section{Diagnosis}

Shield longer than broad (Fig. 2A, E). Ocular peduncles each having the same length, slightly shorter than the shield, reaching beyond both antennal and antennular peduncles; ocular acicles with straight mesial margins. Ocular acicles triangular to subtriangular shape with 3 marginal spines. Antennular peduncles reaching an almost end of ocular peduncle. Cheliped subequal; right slightly longer (Fig. 2B). Dactylus distinctly larger than palm; upper margin with sparsely distributed small tubercles or spines. Carpus slightly wider than longer with a single prominent spine on dorsomesial margin.

Ambulatory legs generally similar; but the third pair longer than the second one (Fig. 2C). Dactyli of the third pair is longer than propodi. Telson with barely detectable median cleft separating posterior lobes (asymmetrical), left lobe is larger than right with 5-6 corneous tipped spines, right margin with 2-4 spinules, both spine rows not 
extending onto lateral margin (Fig. 2D). Shield creamish white. Chelipeds, ambulatory legs, ocular and antennular peduncles with reddish brown colour. Antennal peduncle brown with a light brown flagellum.

\section{Remarks}

Reported from Indonesia, Japan, Taiwan, Australia, East Indian Ocean from Kenya to Arabian Sea, Vietnam, South China Sea, Philippine Islands, New Caledonia, French Polynesia and India.In India, this species is reported so far from Kerala and Bay of Bengal (Reshmi, 2014 and Alcock, 1905).

Clibanarius zebra Dana, 1852

Pagurus zebra Dana, 1852

\section{Materials examined}

Collected from rocky intertidal areas of Danapani and Srivardhan; Number of specimens examined: 48, 27 male (SL: 2.84$5.21 \mathrm{~mm}$ ) and 21 female (SL: 2.2-4.13mm).

\section{Diagnosis}

Shield less broader than length; rostrum triangular (Fig. 3A). Ocular peduncles slightly shorter than shield; ocular acicles terminating with a spine. Ocular peduncles slightly shorter than or as same as antennular peduncles; antennal peduncles hardly reaching the base of the eye. Chelipeds subequal; robust left slightly shorter than right (Fig. 3D). Palm's dorsal surface with few corneous-tipped spines; dorsomesial margins of carpi with a prominent spine distally. Distal half of dactyls of ambulatory legs with few closely-spaced spinules at the ventral margin (Fig. 3C) Telson having shallow median cleft with asymmetrical posterior lobes; terminal margins with 2-3 corneous tipped spines (Fig. 3B). Ocular peduncles without stripes, Ambulatory legs, propodus and dactyl bluishorange.

\section{Remarks}

The distribution of this species so far reported only from Indian Ocean (Thomas, 1989).

Genus: Diogenes Dana, 1851

Diogenes alias McLaughlin \& Holthuis, 2001

Pagurus diogenes: Fabricius 1787: 327; Cancer diogenes 1791: 17, Diogenes miles Heller 1865: 83; Diogenes diogenes. Henderson 1893; Diogenes alias McLaughlin \& Holthuis 2001: 256.

\section{Materials examined}

Collected from subtidal regions of Versova; Number of specimens examined: 31,16 male (SL: 7.45-10.73mm) and 15 female (SL: 6.89$8.12 \mathrm{~mm})$.

\section{Diagnosis}

Shield broader than long, sub rectangular shaped (Fig. 4A). Rostrum obtuse; lateral projections each with small submarginal spinule. Ocular peduncles equal in length, long and stout; ocular acicles with straight mesial margins. The intercalary rostral process usually reaching beyond anterior margins of ocular acicles. 
Fig.1 Location of sampling sites

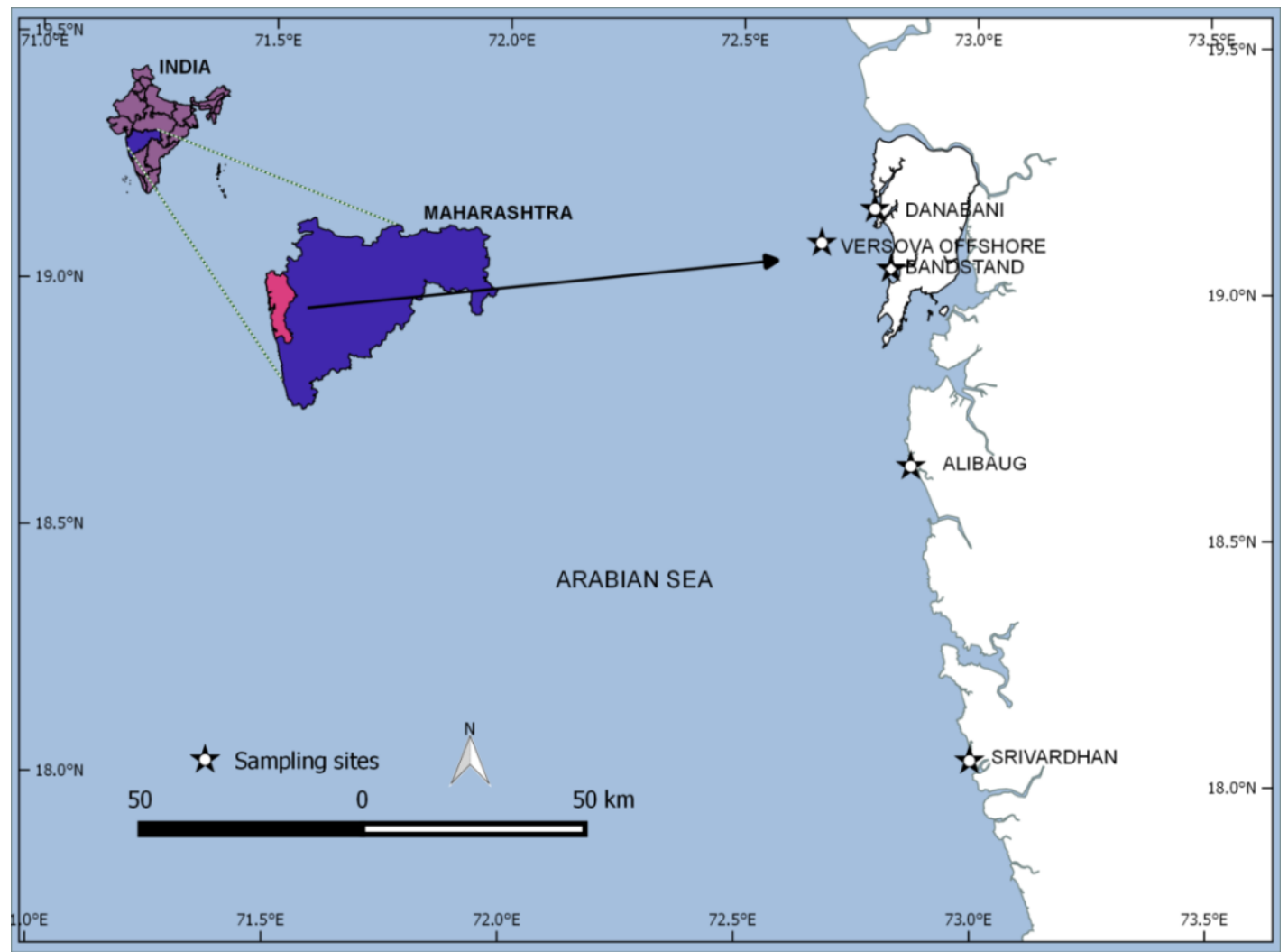

Fig.2 Clibanarius arethusa De Man, 1888: A) Whole animal B) Cheliped C) Right pereiopod D) Telson E) Sheild

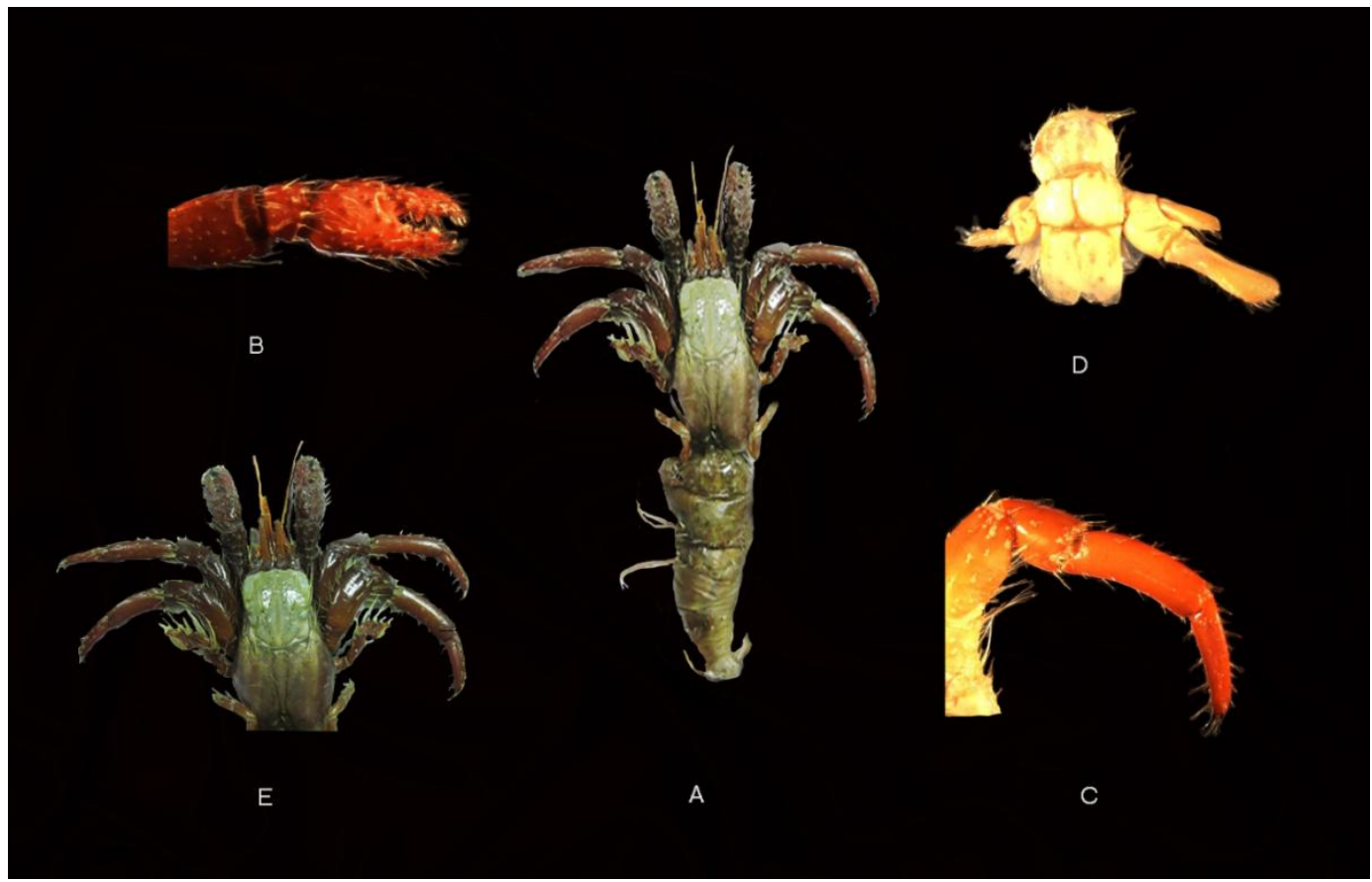


Fig.3 Clibanarius zebra Dana 1852: A) Whole animal B)Telson

C) Right pereiopod D) Cheliped

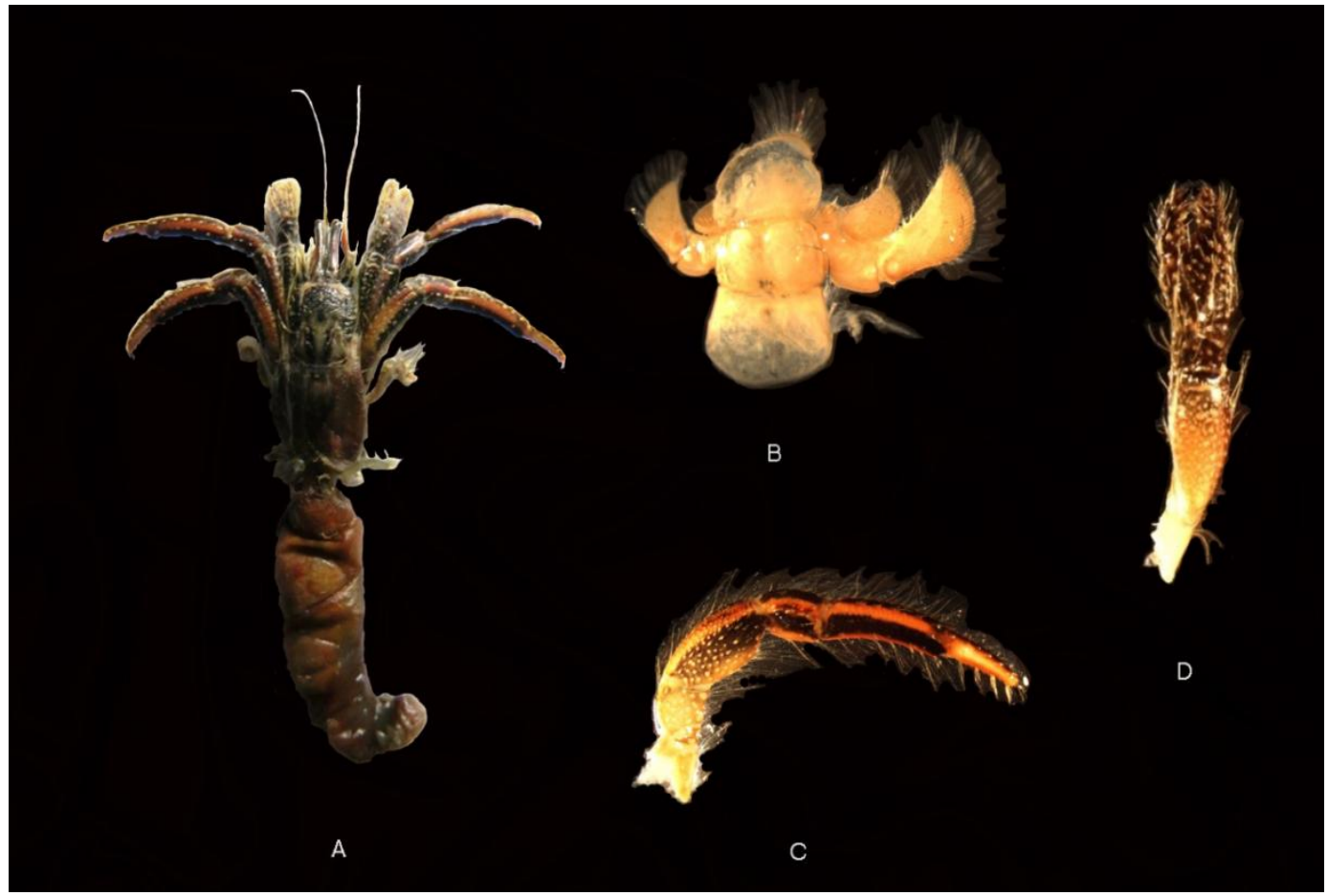

Fig.4 Diogenes alias McLaughlin \& Holthuis, 2001: A) Whole animal B) Cheliped C) Telson D) Third maxilliped E) Right pereiopod

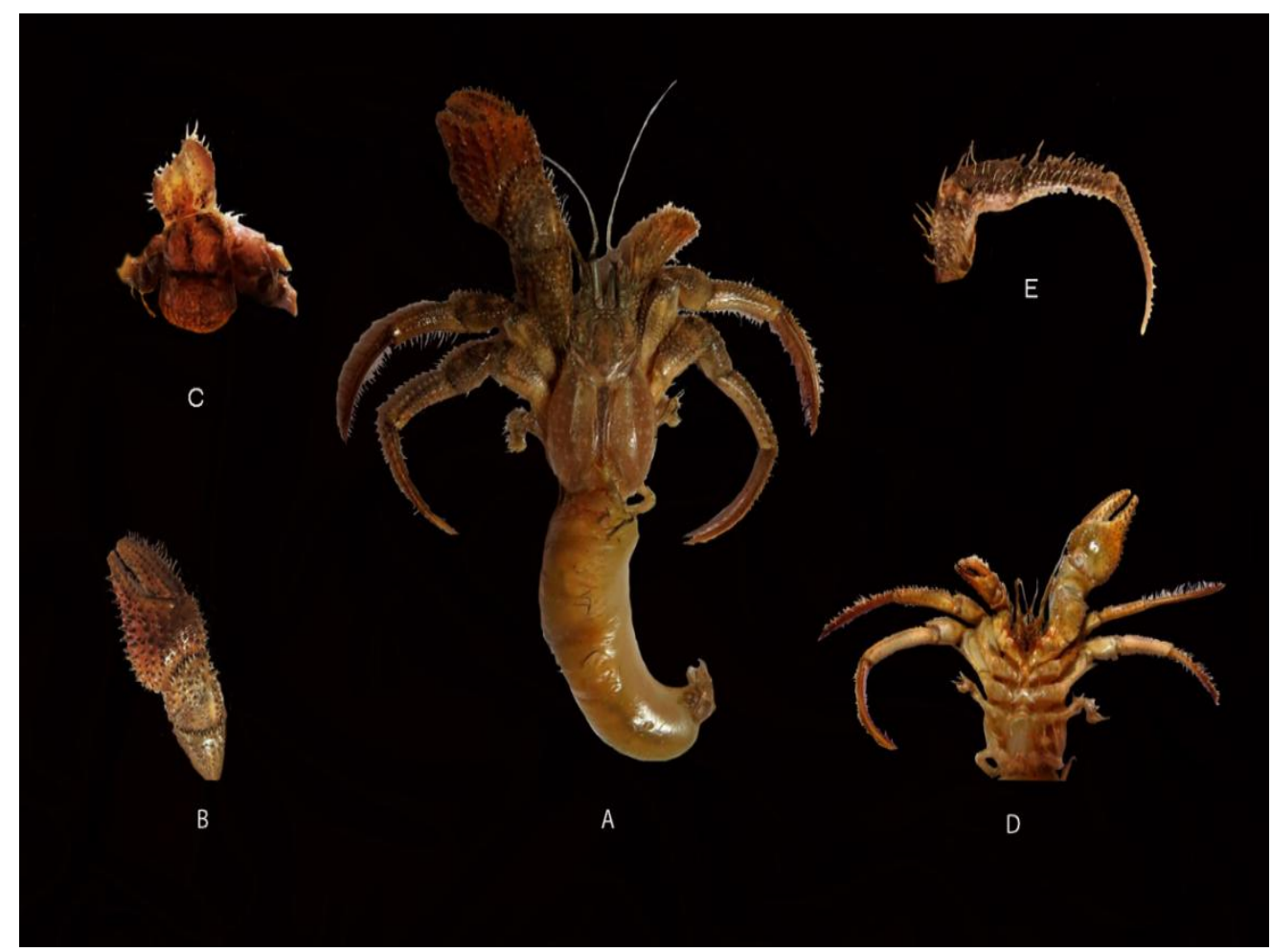


Fig.5 Pagurus pitagsaleei McLaughlin, 2002: A) Whole animal B) Right pereiopod C) Telson D) Cheliped

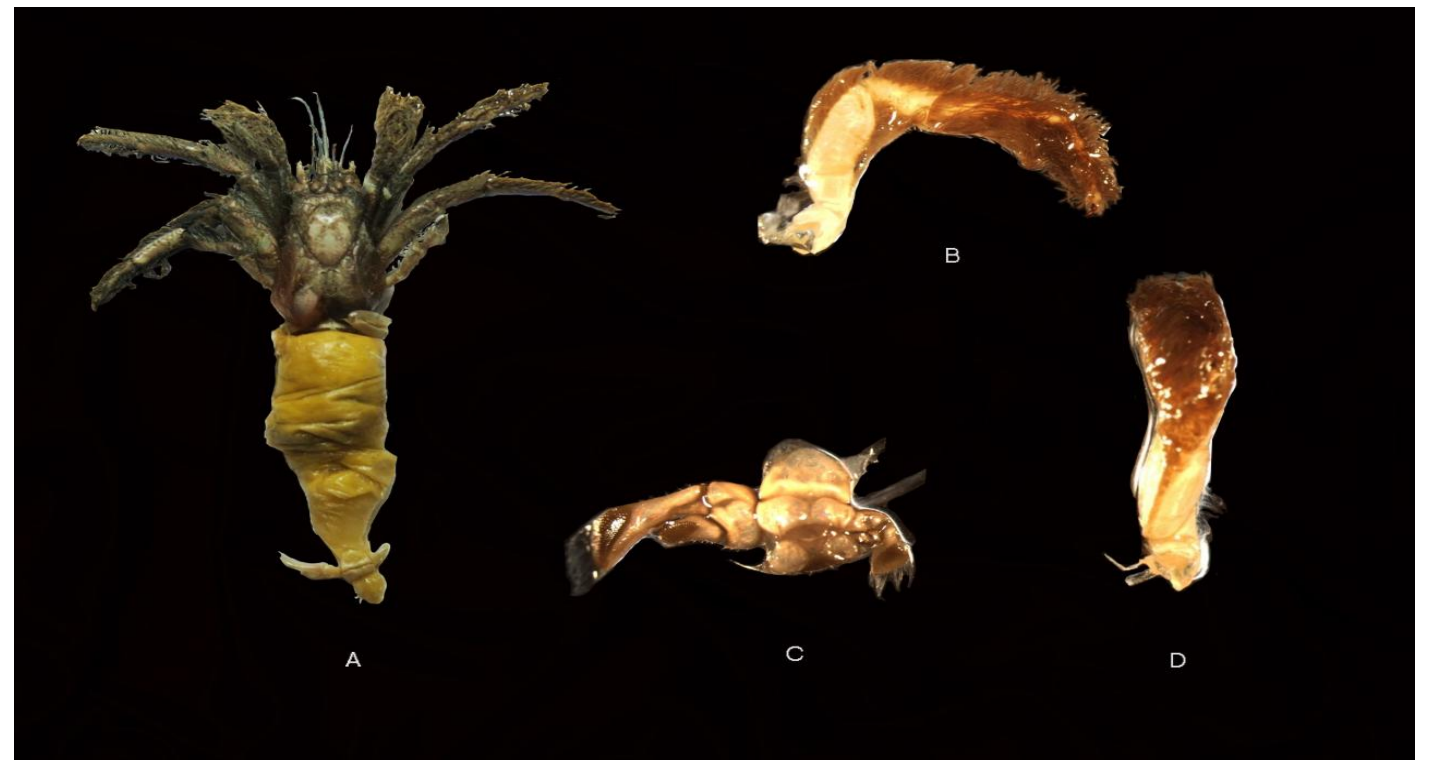

Antennular peduncles over reaching cornea. Antennal acicles outer branches reaching to or beyond the last peduncular segment. Chelipeds unequal left cheliped larger and with a row of slender, sharp spines near the upper outer margin of dactyli (Fig. 4B). Right cheliped with 1 or 2 rows of sharp spines on the upper margin of dactyl. Ambulatory legs generally similar, but the third pair longer than the second one (Fig. 4D, 4E). Dactyli is longer than propodi. Propodi with 3 longer prominent spines on the dorsal surface. Carpi, each with a row of spine at upper margin. Median cleft separating asymmetrical posterior lobes is absent in telson (Fig. 4C), left terminal margin with 5-6 corneous tipped spines noticeably increasing towards posterior margin. Shield cream coloured with a brownish tinge. Ocular peduncle with a light brown longitudinal stripe. Chelipeds, ambulatory legs, antennae, antennules creamish-brown.

\section{Remarks}

Reported from Pakistan, Indonesia, Eastern coast of India including Nicobar Islands and
South China Sea. Their distribution in India so far reported from Kerala, Tamil Nadu, Karnataka and Gujarat (Trivedi et al., 2015, Reshmi, 2014 and Rahayu, 2000).

Family: Paguridae

Genus: Pagurus

Pagurus pitagsaleei McLaughlin, 2002

Pagurus cf. boriaustraliensis - Rahayu \& Komai, 2000: 30; Pagurus pitagsaleei McLaughlin, 2002: 444.

\section{Materials examined}

Collected from rocky intertidal areas of Bandstand and Alibaug; Number of specimens examined: 3, 2 male (SL: 5.43, $5.8 \mathrm{~mm}$ ) and 1 female (SL: $2.9 \mathrm{~mm}$ ).

\section{Diagnosis}

Shield longer than broad (Fig. 5A). Rostrum moderately obtuse, broadly rounded rostrum. Ocular acicle is terminating in a single submarginal spine. Ocular peduncles equal in 
length, long and narrow, inflated at base; ocular acicles with straight mesial margins, anterolateral margin bearing 6-7 spinules. Right cheliped larger not appreciably longer than left (Fig. 5D). Dactyl with a longitudinal median ridge, a row of small closely spaced spines on the dorsomesial margin. Left cheliped dorsomesial region with 3-4 prominent spines, dorsolateral margin with a row of spines. Carpus with a row of 3 large prominent spines on dorsomesial margin, dorsolateral margin with 3-4 spines. Ambulatory legs generally similar, but the third pair longer than the second one (Fig. 5B). Dactyli of third pair exactly same as propodi; 7-8 minute spines present in between 2 rows of tufts of setae on ventral margin. Each carpi with a spine at the dorsodistal end and propodi with 3 spines on ventral margin. Telson with deep median cleft separating asymmetrical posterior lobes, terminal margin with 6-7 corneous tipped spines noticeably increasing towards laterally (Fig. 5C). Shield with brownish grey, ocular peduncle greyishwhite with short longitudinal black stripes and laterally with one longitudinal stripe. Antennal peduncles greyish-white with black stripes, flagella with black and grey bands. Chelipeds palm with greyish-white and black. Carpus and merus of cheliped with few short black stripes. Ambulatory legs with greyishwhite with discontinuous short black stripes.

\section{Remarks}

Reported from Phuket, Thailand, Western Indian Ocean and Northeast Taiwan. This species is recorded for the first time in Indian waters by Reshmi, 2014 and the present collection is second next to it from Maharashtra region.

\section{Acknowledgement}

The authors are thankful to Director, CIFE for providing facilities and encouragement during the study. The help and guidance given for identification by R. Reshmi, Trivesh Jignesh and Ravineesh is acknowledged.

\section{References}

Alcock, A., 1905. Anomura. Fascicle 1. Pagurides Catalogue of the Indian decapod Crustacea in the collection of the Indian Museum, 2: 1-197.

Conover M R., 1978. The importance of various shell characteristics to the shell selection behavior of hermit crabs. $J$. Exp. Mar. Biol. Ecol, 32(2): 131-142.

Hazlett, B. A., 1983. The behavioral ecology of hermit crabs. Ann. Rev. Ecol. Syst. 12: 1-22.

Henderson, J. R. 1915. Hermit-crabs from the Chilka Lake. Records of the Indian Museum, 11: 25-29.

Khan, S. A., and Natarajan, R. 1984. Hermit crabs of Proto Novo Coast. Records of the Zoological Survey of India, Occasional Paper, 67: 1-25.

Komai, T., Reshmi, R. and Kumar, A. B. 2012. A new species of the hermit crab genus Ciliopagurus Forest (Crustacea: Decapoda: Anomura: Diogenidae) from southern India. Zootaxa, 61: 10663.

Komai, T., Reshmi, R. and Kumar, A. B. 2013. A new species of the hermit crab genus Diogenes (Crustacea: Decapoda: Anomura: Diogenidae) from southern India. Zootaxa, 3613 (4): 380-390.

Komai, T., Reshmi, R. and Kumar, A. B. 2015, A new species of the hermit crab genus Paguristes Dana, 1851 (Crustacea: Decapoda: Anomura: Diogenidae) from southwestern India. Zootaxa, 3937 (3): 517-532.

Martin, J. W., and Davis, G. E. 2001. An updated classification of the Recent Crustacea. - Natural History Museum of Los Angeles County, Science Series 39: $1-124$.

McLaughlin, P. A., 2003. Illustrated keys to 
families and genera of the superfamily Paguroidea (Crustacea: Decapoda: Anomura), with diagnoses of genera of Paguridae. Memoirs of Museum Victoria, 60(1): 111-144.

Rahayu, D. L., and Komai, T., 2000. Shallowwater hermit crabs (Crustacea: Decapoda: Anomura: Diogenidae and Paguridae) of Phuket, Thailand. Phuket MarineBiological Center (63).

Reddi, A. R., 1935. Notes on a collection of Paguridea from Porto Novo. Current Science, 3:561-562.

Reese, E. S., 1969. Behavioral Adaptations of Intertidal Hermit Grabs. American Zoologist, 9(2): 343-355.

Reshmi, R., 2014. Taxonomy and diversity of anomuran crabs (Decapoda, Anomura) of Kerala coast, Ph. D thesis, Kerala University.

Reshmi, R., and Bijukumar, A. 2010. First report of the hermit crabs Ceonobita brevimanus and Coenobita rugosus (Crustacea: Decapoda: Anomura) from theIndian coast. Marine Biodiversity Records, 3: 1-4

Reshmi, R., and Bijukumar, A. 2011. New records of hermit crabs, Calcinus morgani Rahayu \& Forest, 1999 and Diogenes klaasi Rahayu \& Forest, 1995 (Crustacea: Anomura: Diogenidae) from India. Journal of Threatened Taxa, 3:1771-1774.

Sankolli, K. N., 1961. On a new species of hermit crabs, Pagurus kulkarnii, (Anomura, Paguridae). J. Zool. Soc. India, 13: 136-142.
Sarojini, R., and Nagabhushanam, R., 1972. Pagurid crabs (Decapoda, Anomura) from Waltair coast. Records of the Zoological Survey of India, 66(1-4): 249-272.

Southwell, T., 1906. Actiniaria. Report to the Government of Ceylon on the Pearl Oyster Fisheries of the Gulf of Mannar Pt. V: 451-451.

Sundara Raj, B., 1927. Order Decapoda. Suborder Anomura (Anomala). In the littoral fauna of Krusadai Island in the Gulf of Mannar with appendices on the vertebrates and plants. Bulletin of the Madras Government Museum, n.s. Natural History Section, 1:129-134.

Teoh, H. W., and Chong, V. C., 2014. Shell use and partitioning of two sympatric species of hermit crabs on a tropical mudflat. Journal of Sea Research, 86: 13-22.

Thomas, M. M., 1974. Decapod crustaceans new to the Laccadive archipelago. J.mar.biol.Ass. India, 339-344.

Thomas, M. M., 1977. Decapod crustaceans new to the Andaman and Nicobar Islands. J.mar.biol.Ass. India, 56-61.

Thomas, M. M., 1989. On a collection of hermit crabs (sic) from the Indian waters. J.mar.biol.Ass. India.31:59-79.

Trivedi J. N., Soni, G. M., Trivedi, D. J., Purohit, B. D. and Vachhrajani, K. D. 2015. On new records of hermit crabs (Anomura; Paguroidea- Diogenidae) from Gujarat state of India. Electronic J. Environmental Sciences. 8: 33-42.

\section{How to cite this article:}

Nirmal, T., A.K. Jaiswar, S.K. Chakraborty, A. Pavan Kumar, G. Kantharajan and Nuzaiba, P.M. 2017. New Records of Hermit Crab (Crustacea: Decapoda: Anomura) from Maharashtra Coast of India. Int.J.Curr.Microbiol.App.Sci. 6(8): 2871-2878. doi: https://doi.org/10.20546/ijcmas.2017.608.343 